Counsellia: Jurnal Bimbingan dan Konseling, 10 (2), $2020 \mid 147$ - 159

Copyright @2020 Universitas PGRI Madiun

ISSN: 2088-3072 (Print) / 2477-5886 (Online)

Available online at: http://e-journal.unipma.ac.id/index.php/JBK

DOI: 10.25273/counsellia.v10i2.7569.

\title{
Konseling Kelompok Singkat Berorientasi Solusi menggunakan media boneka untuk mengurangi agresivitas Siswa
}

\author{
Syska Purnama Sari ${ }^{1}$, Miftha Indasari ${ }^{2}$, Endang Surtiyoni ${ }^{3}$ \\ ${ }^{1}$ Fakultas Keguruan dan Ilmu Pendidikan, Universitas PGRI Palembang, \\ Palembang \\ syskapurnamasari@gmail.com \\ ${ }^{2}$ Fakultas Keguruan dan Ilmu Pendidikan, Universitas PGRI Palembang, \\ Palembang \\ mifthaindasari21@gmail.com \\ ${ }^{3}$ Fakultas Keguruan dan Ilmu Pendidikan, Universitas PGRI Palembang, \\ Palembang \\ surtiyoniendang@gmail.com
}

\begin{abstract}
Abstrak
Aksi kekerasan merupakan bentuk dari agresivitas harus segera diselesaikan. Salah satu alternatif untuk menyelesaikan masalah agresivitas adalah menggunakan boneka dalam konseling kelompok singkat berorientasi solusi. Penelitian ini bertujuan untuk mengetahui keeefektifan pendekatan konseling singkat berorientasi solusi dengan menggunakan media boneka untuk mengatasi masalah agresivitas siswa. Jenis penelitian adalah kuantitatif dengan metode eksperimen, model penelitian adalah pretest posttest one grup desain. Subyek penelitian adalah siswa kelas III Sekolah Dasar di Dusun Meritai. Setelah melakukan analisis data, hasil yang diperoleh adalah terdapat perbedaan yang signifikan antara kondisi agresivitas siswa sebelum dan setelah diberikan perlakuan dengan konseling kelompok singkat berorientasi solusi yang menggunakan media boneka. Sehingga penggunaan boneka dalam konseling singkat berorientasi solusi dapat digunakan oleh guru BK sebagai alternatif untuk mereduksi perilaku agresif.
\end{abstract}

Kata kunci: Konseling Kelompok Singkat Berorientasi Solusi, Media Boneka, Agresivitas.

\begin{abstract}
Violence which is part of aggressiveness and must be resolved. An alternative to resolving aggressiveness is to use dolls in solution focused brief group counseling. The purpose of this research is to observe the effectiveness of solution focused brief counseling using puppet media to reduce aggressiveness. This type of research is quantitative with the experimental method and the model is pretest posttest one group design. The research subjects were third grade elementary school students in Meritai village. The results of the study, it was a significant difference between the aggressiveness before and after being given solution focused brief group counseling using puppet media. So the conclusion is that the use of dolls in solution focused brief counseling can be used by counseling teachers as an alternative to reduce aggressiveness.
\end{abstract}

Keywords: Solutions Focused Group Brief Counseling, Puppets Media, Aggressiveness. 


\section{PENDAHULUAN}

Isu-isu yang dilakukan oleh anak-anak dan remaja dalam waktu dekat ini yang mengkhawatirkan orang tua dan guru adalah mengenai kekerasan. Aksi-aksi kekerasan yang dilakukan baik secara massal ataupun individu sudah tidak asing kita lihat, kekerasan tersebut terjadi lingkungan sekolah, rumah ataupun masyarakat. Bentuk kekerasan yang dilakukan dalam bentuk verbal (menghina) dan non-verbal (memukul ataupun menyerang). Apalagi zaman modern seperti saat ini kekerasan juga dilakukan melalui media sosial. Banyak sekali anak yang menjadi tidak percaya diri karena menjadi korban kekerasan yang dilakukan oleh teman-temannya sendiri. Sebagimana hasil penelitian mengemukakan bahwa kekerasan verbal berpengaruh langsung negatif terhadap kepercayaan diri (Vega et al., 2019).

Berita terbaru seorang siswa SMA Taruna Indonesia di Palembang jadi korban dari tindakan kekerasan yang dilakukan oleh salah seorang seniornya (Rangga Erfizal, 2019). Kasus seperti ini bukan sekali ini saja terjadi, masih banyak mahasiswa dan pelajar yang meninggal karena kegiatan ospek yang kelewat batas. Hal ini sangat memprihatinkan, apalagi terjadi pada lingkungan dunia pendidikan. Di dalam dunia pendidikan yang seharusnya mendidik generasi muda menjadi generasi untuk berkembang dengan baik tetapi terdapat perilaku-perilaku yang sangat tidak patut untuk dilakukan. Selain itu terdapat kasus kakak menusuk adik menggunakan pisau dapur karena berkata kasar (Riski Maruto, 2020). Perilaku-perilaku seperti ini merupakan salah satu bentuk nyata perilaku agresif pada remaja. Agresif adalah perilaku seseorang yang menampilkan tindakan yang dapat membahayakan fisik orang lain dan dirinya sendiri (Estévez López et al., 2008).

Menurut Berkowitz bentuk-bentuk agresivitas yaitu afektif agresif dan reaktif Agresif. Afektif agresif adalah perilaku yang impulsif, sedangkan reaktif agresif merupakan perilaku agresif instrumental yang direncakan untuk merugikan korban dan bersikap proaktif bukan reaktif (Berkowitz, 1993). Selain itu menurut kronenberger dkk mengemukakan bahwa terdapat salah satu bentuk agresif adalah agresi fisik bentuk agresif fisik adalah memukul, menendang, mencubit, ancaman kekerasan, mengambil obyek, dan lain sebagainya (Kronenberger et al., 2005). Jadi dari kedua ahli tersebut dapat disimpulkan agresivitas terjadi karena stimulus berbahaya yang diarahkan pada individu lain disebabkan oleh permusuhan, provokasi dan marah, yang apabila provokasi tersebut diikuti maka dapat meningkatkan agresi.

Agresivitas tidak hanya dilakukan oleh remaja saja, anak usia sekolah dasar juga banyak ditemukan memiliki tingkat agresivitas yang tinggi. Hasil penelitian dari Setiowati mengemukakan bahwa lebih dari 10 persen anak dan remaja yang tinggal di daerah beresiko memiliki tingkat agresivitas kategori tinggi sedangkan rata-rata tingkat agresivitas anak dan remaja pada daerah tersebut sebagian besar berada apada kategori sedanga (Setiowati et al., 2010). Data dari KPAI dalam kurun Januari-Oktober 2017, terdapat 320 anak melakukan aktivitas kriminalitas (BPS, 2018). Selain itu juga pada bulan januari sampai tanggal 13 februari 2019, terdapat laporan 24 kasus kekerasan kepada Komisi Perlindungan Anak Indonesia (KPAI) yang dialami oleh anak, baik sebagai pelaku dan juga sebagai korban di sektor pendidikan. (Abdi, 2019). Hasil penelitian dari Leonard mengatakan bahwa dengan melihat anak ketika berusia 8 tahun, maka dapat diketahui tingkat agresivitas anak tersebut pada saat menjelang dewasa (Setiowati et al., 2010). Dengan melihat anak usia sekolah dasar, maka dapat diketahi agresivitasnya pada saat dewasa (Goldstein et al., 2008). Sehingga apabila perilaku agresif belum diatasi, maka akan menyebabkan aspek perkembangan individu tersebut tidak dapat berkembang dengan optimal, karena akan menyebabkan individu tersebut 
sering berkelahi, melakukan tindakan kekerasan bahkan yang paling parah akan melakukan pelanggaran hukum.

Tingkat agresivitas tinggi yang dimiliki oleh anak dan remaja, harus segera diselesaikan sejak dini agar dapat mencegah perilaku-perilaku yang lebih berbahaya pada masa yang akan datang. Seperti dari hasil penelitian dari Setiwati adalah agresivitas yang dimililiki oleh anak-anak dan remaja dapat menjadi prediksi bagi masalah anti sosial mereka selanjutnta (Setiowati et al., 2010). Sehingga populasi penelitian yaitu siswa Sekolah Dasar, dengan tujuan agar dapat mereduksi agresivitas siswa Sekolah Dasar dan sebagai tindakan preventif untuk masalah anti sosial berikutnya. Untuk itu peran Bimbingan dan Konseling sangat dibutuhkan, upaya Bimbingan Konseling untuk membantu siswa Sekolah Dasar mengatasi perilaku agresif yaitu melalui layanan responsif. Menurut Asosiasi Bimbingan dan Konseling adalah intervensi secara singkat dapat dilakukan oleh Guru Bimbingan dan Konseling dalam konteks memberikan layanan responsif kepada siswa di sekolah dasar (Kemendikbud, 2016).

Peneliti memilih strategi untuk mengatasi masalah agresivitas siswa yang tinggi menggunakan strategi konseling kelompok. Menurut Sukardi layanan konseling kelompok adalah layanan di dalam bimbingan dan konseling yang memberikan kesempatan kepada peserta didik untuk membahas dan menyelesaikan masalah yang dialaminya melalui dinamika kelompok (Sukardi, 2000). Selain itu layanan konseling kelompok merupakan bantuan yang diberikan untuk membantu memecahkan masalah siswa dengan memanfaatkan dinamika kelompok (Nasrina Nur Fahmi, 2016). Selain itu menurut Prayitno, setiap anggota kelompok diharapkan mampu mandiri untuk mengembangkan dirinya agar dapat malakukan hubungan dengan orang lain melalui dinamika kelompok (Prayitno, Afdal, Ifdil, 2017). Sehingga strategi konseling kelompok dipilih dengan harapan siswa yang memiliki agresivitas yang tinggi dapat mengurangi tingkat agresivitasnya dalam dinamika kelompok, di dalam kelompok itu juga diharapkan siswa dapat mengendalikan perilaku agresifnya. Karena mereka juga berhadapan langsung dengan teman-teman yang juga memiliki agresivitas tinggi, sehingga mereka bisa menilai sendiri ketika melihat orang lain yang memiliki agresivitas tinggi.

Hasil penelitian dari Fitriyah menjelaskan bahwa perilaku agresif siswa SMA Negeri 1 Singgahan, dapat direduksi dengan konseling singkat berorientasi solusi (Fitriyah, 2014). Hasil penelitian lain juga mengemukakan bahwa remaja yang mengalami agresivitas dan diberikan konseling dengan pendekatan konseling singkat berorientasi solusi ini dapat berhasil diturunkan tingkat agresivitasnya (Baskoro, 2013). Selain itu hasil penelitian dari Putri dkk menyatakan bahwa tingkat agresivitas siswa memiliki perbedaan antara sebelum dan sesudah diberikan perlakuan dengan solution focused brief counseling berbasis seni kreatif (Putri et al., 2019).

Berdasarkan ketiga penelitian tersebut jelaslah bahwa konseling singkat berorientasi solusi dapat mereduksi agresivitas siswa. Sehingga peneliti akan menggunakan strategi konseling kelompok dengan pendekatan konseling singkat berorientasi solusi menggunakan media boneka. Konseling singkat berorientasi solusi merupakan konseling yang dilakukan dengan efektif dan efisien karena waktu konseling terbatas dan terfokus pada kompetensi, kekuatan, kemungkinan dan upaya solusi (Sugara, 2019). Fokus konseling singkat berorientasi solusi adalah cara siswa mengatasi permasalahan yang dihadapinya pada saat ini dan apa yang akan mereka lakukan untuk menyelesaikan masalahnya (Kegley, 2000). Dalam pendekatan ini, strategi yang digunakan adalah konseling kelompok dengan harapan siswa yang akan diberikan konseling dapat lebih semangat dalam menjalankan proses konseling karena konseling 
dilakukan dalam bentuk kelompok, dimana anggota kelompok merupakan teman-teman dari kelas yang sama dan desa yang sama, karena untuk anak usia sekolah dasar mereka senang melakukan kegiatan bersama kelompoknya, dan dilakukan sambil bermain.

Untuk itu dalam memberikan intervensi dengan menggunakan pendekatan konseling kelompok singkat berorientasi solusi kepada siswa agresif di Sekolah Dasar, pada penelitian ini menggunakan media boneka karena konseli yang akan dikonseling merupakan siswa Sekolah Dasar. Agar terdapat perbedaan dengan ketiga penelitian yang sudah dijelaskan sebelumnya, karena dari ketiga penelitian sebelumnya hanya melakukan konseling dengan pendekatan konseling singkat berorientasi solusi tanpa menggunakan media apapun. Sehingga peneliti pada penelitian ini melakukan inovasi menggunakan media boneka dan dengan strategi konseling kelompok. Karena dari subyek penelitian yang merupakan siswa Sekolah Dasar, yang memiliki karakteristik senang bermain dan berkelompok. Harapannya dengan menggunakan boneka dan strategi konseling kelompok maka konseli akan lebih tertarik dan semangat dalam mengikuti proses konseling. Menurut Wallace \& Mishina (2004) boneka memiliki potensi besar untuk digunakan oleh guru sekolah dasar karena dapat membantu untuk memperbaiki komunikasi, mengatasi hambatan bahasa dan mengajarkan pengendalian diri. Pengendalian diri sangat diperlukan anak yang memiliki agresivitas tinggi, karena menurut Hastuti bahwa dengan adanya kontrol diri maka dapat menghentikan munculnya agresi dan sebaliknya apabila kontrol diri tidak ada maka dapat memperkuat kemunculan agresi (Hastuti, 2018). Oleh karena itu diperlukan penelitian tentang penggunaan boneka dalam konseling singkat berorientasi solusi untuk mereduksi agresivitas siswa sekolah dasar.

\section{METODE PENELITIAN}

\section{Rancangan Penelitian}

Penelitian ini secara umum dilakukan menggunakan metode pre eksperimental dengan menggunakan desain one group pretest posttest. Metode dipilih untuk menguji efektif atau tidak pendekatan konseling singkat berorientasi solusi menggunakan media boneka, keefektifan dianalisis dengan melihat perbedaan tingkat agresivitas siswa sekolah dasar sebelum dengan sesudah penggunaan boneka dalam konseling singkat berorientasi solusi. Dalam penelitian ini hanya menggunakan satu kelompok yang diberikan perlakuan tanpa adanya kelompok kontrol.

\section{Sumber Data}

Penelitian diawali dengan menetapkan sampel secara purposive yaitu siswa sekolah dasar yang memiliki tingkat agresivitas yang tinggi. Sampel penelitian yaitu tujuh orang siswa Sekolah Dasar kelas III di Desa Sungai Pinang Dusun Meritai. Sampel dipilih berdasarkan hasil pretest dengan menggunakan skala agresivitas yang telah diberikan kepada siswa sekolah dasar di Dusun Meritai. Skala agresivitas terlebih dahulu telah melalui uji realibilitas dan validitas, peneliti juga melakukan validasi skala agresvitas kepada tiga orang rekan rekan, yaitu dosen BK, dosen PGSD dan Guru SD. Dari hasil uji validitas terdapat 30 item pernyatan yang teruji valid, dan siap disebarkan kepada siswa sekolah dasar di dusun meritai yang merupakan populasi dari penelitian. Siswa yang memiliki hasil pretest yang tinggi dipilih untuk menjadi konseli dan diberikan konseling dengan pendekatan konseling singkat berorientasi solusi. Sampel penelitian ini juga diambil berdasarkan kriteria-kriteria berikut ini: 1. Siswa kelas III Sekolah Dasar yang memiliki tingkat agresivitas tinggi berdasarkan hasil pretest yang telah diberikan, 2. Siswa harus mendapat persetujuan dari orang tua untuk mengikuti konseling, 3. Siswa dalam keadaan sehat, dan 4. Siswa tidak ada kegiatan pada hari sabtu. 


\section{Teknik Pengumpulan Data}

Pada pertemuan awal dilakukan pengukuran awal mengenai tingkat agresivitas siswa Sekolah Dasar di Desa Sungai Pinang Dusun Meritai. Pengukuran dilakukan dengan memberikan angket tertutup berjumlah 30 item dengan skala agresivitas siswa yang merupakan pengembangan dari teori Buss \& Perry, menyatakan bahwa terdapat empat aspek agresivitas (Buss \& Perry, 1992) yaitu: 1. Physical aggression, adalah tindakan menyakiti, mengganggu, atau membahayakan fisik orang lain, 2. Verbal aggression, yaitu tindakan menyakiti, mengganggu, atau membahayakan orang lain dengan cara verbal misalnya menghina, mencaci, berbohong dan lain sebaginya, 3. Anger, yaitu suatu bentuk reaksi afektif berupa dorongan fisiologis seperti perasaan marah, kesal, sebal, dam 4. Hostility, yaitu agresivitas covert yang tidak kelihatan, seperti cemburu dan iri terhadap orang lain, kecurigaan, ketidak percayaan terhadap orang lain.

Selanjutnya peneliti menerapkan tindakan eksperimen, yaitu menggunakan boneka dalam konseling singkat berorientasi solusi kepada ketujuh sampel penelitian. Penerapan konseling kelompok dilakukan selama enam sesi. Durasi sesi konseling hanya 25 sampai 30 menit. Tahapan setiap sesi sebenarnya dilakukan dengan tahapan yang tidak jauh berbeda, peneliti menggunakan prosedur yang sama pada setiap sesinya. Hanya saja yang sedikit membedakan ada pada sesi pertama, karena pada sesi pertama peneliti harus melakukan tahap attending terlebih dahulu, dimana siswa harus merasa nyaman agar konseling dapat berjalan dengan baik. Selain itu pada sesi pertama juga peneliti fokus pada pertanyaan "mengapa mereka perlu berpartisipasi dalam kelompok". Anggota kelompok mengidentifikasi perilaku yang menjadi masalah bagi mereka dan orang disekitarnya.

Setelah itu sesi pertama juga peneliti dan siswa membuat komitmen untuk belajar bersama agar dapat menghilangkan perilaku agresif yang mereka miliki. Tujuan pada sesi pertama ini adalah agar siswa mengerti dan sepakat untuk akan memperbaiki perilakunya. Pada sesis kedua sampai sesi keenam, siswa dan peneliti melaksanakan konseling sesuai dengan prosedur, diawal sesi siswa pasti ditanyakan mengenai perubahan positif yang telah mereka alami. Tujuan pada sesi kedua sampai enam adalah agar siswa dapat merubah perilaku mereka dan berjanji serta dapat menepati janji tersebut untuk menjadi pribadi yang lebih baik. Adapun prosedur konseling singkat berorientasi solusi pada penelitian ini adalah: 1. Identifikasi tujuan, 2. Mengidentifikasi pengecualian, peneliti menggunakan teknik pertanyaan keajaiban kepada siswa, 3. Memberikan pertanyaan rincian perilaku secara mendetail, peneliti menggunakan pertanyaan hubungan timbal balik, 4. Mengidentifikasi pengalaman keberhasilan di masa lalu, peneliti membantu siswa menemukan tiga pengalaman siswa yang berhasil di masa lalu, 5. Menggunakan pertanyaan skala, peneliti menggunakan emoticon sebagai pengganti pertanyaan skala, emoticon yang paling buruk atau sedih mewakili angka 0 dan emoticon yang paling baik atau bahagia mewakili angka 10 . Kemudian peneliti bertanya kepada siswa, saat itu perasaan mereka berada pada emoticon yang mana, dan 6. Menulis pesan yang terdiri dari pujian, pernyataan yang menjembatani dan tugas, penulisan pesan disini tidak dilakukan dengan menulis secara langsung. Namun peneliti yang membantu menuliskan dan langsung dikatakan oleh siswa.

\section{Teknik Analisis Data}

Tahap pengujian efektifitas penggunaan boneka dalam konseling singkat berorientasi solusi dilakukan secara kuantitatif, anggota peneliti kembali memberikan angket skala agresivitas yang sama terhadap seluruh sampel (post test). Keberhasilan tindakan diukur secara kuantitaif dengan menggunakan uji wilcoxon signed rank test, karena pada penelitian ini akan mengukur perbedaan antara dua kelompok data berpasangan berskala ordinal atau interval, dan data tersebut berdistribusi tidak normal, 
selain itu juga pada penelitian ini sampel yang digunakan berjumlah kecil yaitu berjumlah tujuh orang sampel, dan tidak dapat menambah jumlah sampel lagi. Sehingga analisis data menggunakan statistic non parametric. Analisis data juga dibantu dengan menggunakan program SPSS 21.00.

\section{HASIL DAN PEMBAHASAN}

\section{Hasil Penelitian}

Berikut ini adalah hasil pemaparan data penelitian gambaran pretest dan posttest tingkat agresivitas siswa sekolah dasar terlihat pada tabel dibawah ini.

Tabel.1 Deskripsi Skor Pretest dan Postets Agresivitas Siswa

\begin{tabular}{|c|c|c|c|c|c|c|}
\hline \multirow{2}{*}{ No } & \multirow{2}{*}{ Subyek } & \multicolumn{4}{|c|}{ Skor dan Kategori } & \multirow{2}{*}{$\begin{array}{l}\text { Gain } \\
\text { (d) }\end{array}$} \\
\hline & & \multicolumn{2}{|r|}{ PreTest } & \multicolumn{2}{|c|}{ PostTest } & \\
\hline 1 & $\mathrm{PH}$ & 25 & Tinggi & 6 & Rendah & 19 \\
\hline 2 & $\mathrm{FH}$ & 26 & Tinggi & 7 & Rendah & 19 \\
\hline 3 & DK & 24 & Tinggi & 9 & Rendah & 15 \\
\hline 4 & MY & 25 & Tinggi & 7 & Rendah & 18 \\
\hline 5 & EV & 28 & Sangat Tinggi & 10 & Rendah & 18 \\
\hline 6 & IR & 25 & Tinggi & 9 & Rendah & 16 \\
\hline 7 & DN & 27 & Tinggi & 8 & Rendah & 19 \\
\hline \multicolumn{2}{|c|}{ Total $\mathrm{N}=7$} & \multicolumn{2}{|r|}{180} & \multicolumn{2}{|c|}{56} & 124 \\
\hline \multicolumn{2}{|c|}{ Mean } & \multicolumn{2}{|r|}{25.71} & \multicolumn{2}{|c|}{8} & 17.71 \\
\hline
\end{tabular}

Berdasarkan tabel 1 hasil deskriptif pretest dan posttest agresif siswa, dapat dijelaskan bahwa terdapat penurunan tingkat agresivitas siswa, siswa yang pada saat pretest memiliki tingkat kategori tinggi dan sangat tinggi megalami penurunan pada kategori rendah pada saat diberikan posttest. Hasil pretest, yaitu sebelum diberikan perlakuan rata-rata skor agresivitas siswa yaitu 25.71 sedangkan setelah diberikan perlakuan, rata-rata hasil posttest agresivitas siswa adalah 8 . Sehingga hasil pretest dan posttest terjadi penurunan yaitu dengan skor rata-rata sebesar 17.71 .

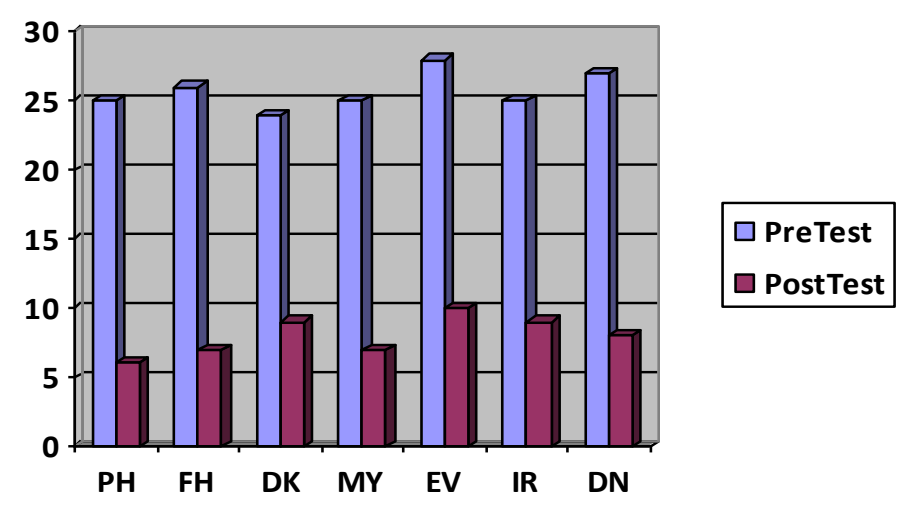

Gambar 1. Perubahan skor agresivitas melalui konseling kelompok dengan pendekatan konseling singkat berorientasi solusi menggunakan media boneka.

Berdasarkan gambar 1 terlihat jelas bahwa terjadi penurunan tingkat agresivitas siswa setelah diberikan perlakuan melalui layanan konseling kelompok dengan pendekatan konseling singkat berorientasi solusi menggunakan media boneka. Dapat 
dilihat pada diagram berwarna merah lebih rendah dari berwarna biru. Sehingga dapat disimpulkan bahwa terjadi penurunan skor agresivitas siswa setelah diberikan perlakuan.

Untuk menguji hipotesis dalam penelitian ini digunakan uji wilcoxon menggunakan bantuan program spss versi 21.00. Hipotesis dalam penelitian adalah "cukup bukti untuk menyatakan bahwa konseling kelompok dengan menggunakan pendekatan konseling singkat berorientasi solusi menggunakan media boneka merupakan metode yang efektif yang dapat digunakan untuk mereduksi agresivitas siswa. Hasil analisis yang telah dilakukan dapat dilihat pada table 3 berikut ini:

Tabel 2. Hasil Analisis Uji Wilcoxcon

\begin{tabular}{cc}
\hline & Posttest-Pretest \\
\hline $\mathrm{Z}$ & $-2,388^{\mathrm{b}}$ \\
\hline Asymp.Sig. (2-tailed &, 017 \\
\hline
\end{tabular}

Berdasarkan tabel hasil analisis Wilxocon signed rank test, angka probalitas Asymp.Sig. (2-tailed) adalah 0.017, atau probalitas dibawah Alpha 0,05 (0,017 < 0,05). Dari perolehan hasil maka dapat diseimpulkan Ho ditolak dan Ha diterima. Dengan demekian, maka hipotesis dalam penelitian ini diterima.

Tabel 3. Arah Perbedaan Pretst dan Posttest Tingkat Agresivitas Siswa

\begin{tabular}{lccc}
\hline & $\mathrm{N}$ & Mean & Sum \\
\hline $\begin{array}{l}\text { Posttest-Pretest Negative } \\
\text { Ranks }\end{array}$ & $7^{\mathrm{a}}$ & 4.00 & 28.00 \\
\hline Positive Ranks & $0^{\mathrm{c}}$ & .00 & .00 \\
\hline Ties & $0^{\mathrm{c}}$ & & \\
\hline Total & 7 & & \\
\hline
\end{tabular}

Berdasarkan table 4 diketahui nilai negative ranks adalah $7^{\text {a }}$ yang berarti tujuh orang siswa yang merupakan sampel penelitian mengalami penurunan tingkat agresivitasnya sebesar 4.00 dengan jumlah keseluruhan sebesar 28.00. Berdasarkan hasil pengujian hipotesis yang telah dilakukan dapat disimpulkan secara rata-rata agresivitas siswa mengalami penurunan setelah mendapat perlakuan konseling singkat berorientasi solusi dengan menggunakan media boneka. Sehingga hasil penelitian menunjukkan keberhasilan dalam mereduksi agresivitas siswa.

\section{Pembahasan}

Agresivitas pada siswa sekolah dasar harus menjadi perhatian karena akan berpengaruh pada kepribadian siswa juga akan mempengaruhi perkembangan mereka ketika remaja, sebagaimana dengan hasil penelitian yang dilakukan oleh Sari bahwa perilaku agresif yang dibiarkan akan berdampak buruk pada perkembangan remaja (Sari, 2016). Selain itu menurut Ondawati bahwa perilaku agresif akan memberikan dampak negatif bagi siswa dan orang lain di sekitar siswa, korban kekerasan akan memiliki masalah kesehatan dan masalah kehidupan (Ondawati, 2019). Penelitian yang telah dilakukan untuk mereduksi agresivitas siswa sekolah dasar sangat tepat, karena dapat mencegah kenakalan-kenakalan pada usia remaja dan dapat mencegah timbulnya masalah dalam kehidupan korban dari perilaku agresivitas. Sehingga penelitian untuk menyelesaikan masalah agresivitas siswa sekolah dasar diharapkan akan berdampak baik bagi pelaku dan korban. Hal yang sama diungkapkan oleh Sara et al adalah kita dapat mengetahui tingkat agresivitas anak pada usia dewasa, hanya dengan memperhatikan bagaimana anak tersebut pada waktu masih usia sekolah dasar (Sari, 2017). Pendapat yang sama juga dikemukakan oleh Chotim dan Affifah bahwa perilaku merusak pada 
anak ditahap selanjutnya akan terus berkembang apabila perilaku tersebut menjadi kebiasaan anak (Chotim dan Affifah, 2011).

Untuk mereduksi agresivitas siswa sekolah dasar, dilakukan penelitian dengan memberikan konseling singkat berorientasi solusi menggunakan boneka. Penelitian dilakukan dengan menggunakan strategi konseling kelompok, karena siswa yang akan dikonseling merupakan siswa sekolah dasar, salah satu karakteristik siswa sekolah dasar adalah senang bermain dan berkelompok. Seperti yang diejlaskan oleh Hurlock bahwa anak mempunyai hubungan yang erat dengan berbagai anggota kelompok tertentu (Hurlock, 1999). Selain itu, dalam penelitian ini juga akan memberikan intervensi kepada siswa yang memiliki tingkat agresivitas yang tinggi, sehingga masalah yang dimiliki oleh siswa merupakan masalah sosial. Menurut Prayitno dkk bahwa apabila konseli yang dibantu memerlukan bantuan untuk tujuan yang berkaitan dengan dinamika kelompok, misalnya untuk mengembangkan kemampuan hubungan sosial, maka layanan konseling kelompok yang lebih tepat untuk dijadikan strategi, sehingga konseli dapat dilibatkan dalam menjalani dinamika kelompok yang aktif (Prayitno, Afdal, Ifdil, 2017). Sehingga peneliti menggunakan strategi bimbingan kelompok dengan pendekatan konseling singkat berorientasi solusi menggunakan media boneka untuk menyelesaikan masalah agresivitas siswa. Dan hasil dari penelitian adalah pendekatan konseling singkat berorientasi solusi dengan menggunakan media boneka efektif untuk mereduksi tingkat agresivitas siswa yang tinggi. Hasil penelitian dikatakan efektif selain dari uji wilcoxon signed rank test. Peneliti juga melakukan observasi perilaku agresvitas ketujuh konseli selama proses konseling berlangsung. Proses konseling dilaksanakan sebanyak enam sesi.

Sesi Pertama, peneliti membuka pertemuan sesi kelompok dengan fokus pertanyaan mengapa mereka perlu berpartisipasi dalam kelompok. Anggota kelompok mengidentifikasi perilaku agresif mereka seperti senang memukul, menghina, berkata kasar, bahkan berkelahi dengan teman ataupun saudara baik di rumah, di luar rumah ataupun di sekolah. Setelah itu peneliti dan anggota kelompok membuat komitmen untuk belajar bagaimana mengurangi perilaku agresif mereka. Setelah itu peneliti menggunakan boneka tangan dan memberikan pertanyaan keajaiban kepada anggota kelompok yang juga telah menggunakan boneka tangan miliknya untuk mengidentifikasi perilaku mereka jika mereka tidak lagi mudah marah, mudah menghina dan menjadi anak yang lebih baik. Menurut Sugara Pertayaan keajaiaban diberikan dengan tujuan untuk mengklarifikasi tujuan dalam bentuk konkret dan spesifik, menciptakan gambaran tentang kehidupan konseli yang terlihat di masa depan ketika tanpa masalah dan untuk memberikan latihan mental dari apa yang konseli lakukan untuk mencapai tujuan (Sugara, 2019). Selanjutnya setiap siswa diminta untuk menjawab pertanyaan merinci dengan tetap menggunakan boneka tangan. Selanjutnya peneliti membantu setiap anggota kelompok mengidentifikasikan pengalaman-pengalaman keberhasilan konseli dalam mengendalikan perilaku agresifnya di masa lalu.

Selanjutnya peneliti meminta setiap konseli untuk menilai diri mereka sendiri dalam skala. Skala yang digunakan dalam penelitian ini yaitu boneka emoticon, peneliti memberikan 10 emoticon kepada konseli. Emoticon sedih mewakili skala 0 dan emoticon bahagia mewakili skala 10. Setiap konseli yang masih menggunakan boneka tangan diminta untuk memilih emoticon yang mewakili perasaannya saat diberikan pertanyaanpertanyaan keajaiban, dan mereka diminta untuk memberikan alasan telah memilih emoticon tersebut.

Sesi Kedua sampai Enam, anggota kelompok ditanyakan mengenai perubahan positif yang terjadi pada dirinya dari pertemuan pertama sampai pertemuan terakhir. Kemudian siswa diminta untuk menilai diri mereka melalui emoticon sedih sampai bahagia. Peneliti kemudian memberikan dorongan terhadap keberhasilan yang ingin 
dicapai oleh setiap anggota dan menggunakan pertanyaan merinci untuk mengeksplorasi anggota kelompok melakukan perubahan. Anggota kelompok juga merefleksikan dampak perilaku mereka terhadap diri mereka sendiri dan orang lain. Diakhir pertemuan, anggota kelompok diminta berbagi satu sama lain mengenai perbaikan yang telah mereka rasakan dan berharap untuk saling memotivasi satu sama lain. Selain itu peneliti juga memberikan reward berupa pujian dan hadiah-hadiah kepada anggota kelompok yang menunjukkan perubahan perilaku yang lebih baik. Dan juga memberikan punishment kepada anggota kelompok yang menunjukkan perilaku agresif selama proses konseli berlangsung.

Dari enam sesi yang dilakukan terjadi perubahan perilaku agresif pada ketujuh siswa yang memiliki agresivitas tinggi. Dari observasi yang dilakukan selama proses konseling, ketujuh siswa juga menunjukkan perubahan perilaku. Misalnya di sesi pertama rata-rata siswa saling menghina teman yang sedang berbicara, ada juga yang suka memotong pembicaraan teman, bahkan ada yang hampir memukul temannya karena merasa kesal dengan teman tersebut. Namun pada sesi kedua perilaku-perilaku seperti itu sudah bisa mereka kendalikan, bahkan pada pertemua terakhir mereka terlihat lebih baik dalam berperlikau. Observasi juga dilakukan oleh tim peneliti di lingkungan rumah masing-masing konseli. Di rumah rata-rata siswa mampu mengendalikan dirinya untuk tidak mudah marah, tidak berkelahi, dan lebih sabar.

Hasil observasi dan analisis data menunjukkan bahwa penggunaan boneka dalam konseling singkat berorientasi solusi memberikan dampak positif bagi konseli sehingga dapat disimpulkan bahwa treatment yang diberikan efektif untuk mereduksi agresivitas siswa. Hal ini juga didukung dari hasil penelitian Fitryah bahwa konseling singkat berorientasi solusi dapat menurukan perilaku agresivitas siswa (Fitriyah, 2014). Penelitian tersebut dilaksanakan sebanyak tiga kali selama tiga minggu sebanyak empat kali sesi. Strategi layanan yang digunakan adalah konseling individual. Hasil penelitian adalah secara umum konseling singkat berfokus solusi efektif untuk mengurangi agresivitas siswa kelas X SMA N 1 Singgahan. Pendekatan tersebut efektif mengurangi empat subyek perilaku agresif pada aspek agresi fisik, agresi verbal, kemarahan dan permusuhan, namun ada dua subyek tidak efektif untuk mengurangi aspek agresi verbal.

Selain itu juga hasil penelitian dari Putri dkk adalah setelah diberikan perlakuan solution focused brief counseling berbasis seni kreatif maka adanya perbedaan agresif sosial siswa sebelum dan setelah diberikannya perlakuan. Penggunaan seni kreatif pada penelitian ini diawali dengan guru $\mathrm{BK}$ atau konselor meminta konseli membayangkan perilaku agresif soaial mereka dan bersama-sama mencari solusi untuk meyelesaikan masalah perilaku agresif tersebut. Cara yang mereka lakukan adalah menggambar di kertas yang sudah disediakan, dan diakhir dengan konseli menjelaskan makna dari gambar tersebut secara langsung (Putri et al., 2019). Hasil penelitian yang lainnya adalah penelitian dari Baskoro, penelitian yang berjudul model solution focused brief group therapy untuk perilaku agresif remaja. Subyek penelitian adalah 12 orang laki-laki dan perempuan. Hasil penelitian menunjukkan bahwa SFBGT dapat mengurangi agresivitas remaja (Baskoro, 2013).

Ketiga penelitian yang telah dikemukan sebelumnya adalah penelitian terdahulu mengenai konseling singkat berorientasi solusi dan agresivitas siswa. Rata-rata hasil penelitian tersebut mengemukakan bahwa konseling singkat berorientasi solusi efektif menurunkan agresivitas siswa. Dan pada penelitian ini juga telah terbukti bahwa agresivitas siswa dapat dikurangi melalui pendekatan konseling singkat berorientasi solusi. Namun pada penelitian ini, peneliti memberikan inovasi dalam proses konseling, yaitu strategi konseling dilakukan adalah konseling kelompok dan menggunakan media boneka. Inovasi yang dilakukan peneliti menjadi faktor yang mempengaruhi keefektifan pendekatan konseling singkat berorientasi solusi. 
Adapun faktor yang mempengaruhi keberhasilan penggunaan boneka dalam konseling singkat berorientasi solusi yaitu pertama konseling singkat berorientasi solusi menggunakan strategi konseling kelompok, strategi konseling kelompok dianggap efektif dalam penelitian ini, karena di dalam konseling kelompok terdapat dinamika kelompok. Menurut Sucipto dinamika kelompok adalah suasana yang hidup, berdenyut, bergerak, berkembang, dan ditandai dengan adanya interaksi anggota kelompok (Sucipto, 2016). Selain itu juga menurut Prayitno dkk bahwa dinamika kelompok dalam pendekatan kelompok bertujuan membina kemampuan mengendalikan diri, sehingga didalam kelompok dituntut untuk mempunyai sikap menghargai teman, bertenggang rasa dan kebersamaan, disertai dengan pertimbangan mana yang lebih baik dan dapat diterima orang lain, menjadi arahan perilaku pengendalian diri (Prayitno, Afdal, Ifdil, 2017).

Menurut hasil penelitian dari Fitri bahwa layanan konseling kelompok memberikan begitu banyak manfaat untuk membantu mengatasi masalah-masalah siswa, masalahmasalah tersebut antara lain masalah pribadi siswa yaitu dengan mengikuti layanan konseling kelompok maka siswa mampu berkomunikasi dengan baik, siswa dapat mengendalikan diri, dapat melaksanakan persahabatan dengan temannya secara baik. Selain itu konseling kelompok juga dapat membantu menyelesaikan masalah sosial yaitu membantu siswa agar dapat berinteraksi dengan orang lain dan dapat beradaptasi dengan lingkungannya. Kemudian konseling kelompok juga membantu menyelesaikan masalah belajar yaitu membantu siswa agar dapat menyelesaiakan tugas-tugas di sekolah dan memiliki motivasi yang tinggi dalam belajar (Fitri, 2016). Selain itu menurut Abidin salah satu unsur dari konseling kelompok adalah konseling kelompok dapat membantu konseli mengembangkan potensinya sehingga mereka dapat menyesuaikan diri dan menjalankan tugas kehidupannya di rumah, lingkungan sekolah dan lingkungan masyarakat (Abidin, 2009). Jadi jelaslah bahwa konseling kelompok merupakan salah satu faktor yang mempengaruhi keberhasilan penelitian ini. Selama siswa mengikuti proses konseling, siswa dapat belajar untuk memiliki pegendalian diri sehingga dapat mengurangi perilaku agresif dan siswa juga dapat berdiskusi bersama anggota kelompok untuk menyelesaikan masalah yang sedang mereka miliki yaitu memperbaiki perilaku agresif yang akan berdampak buruk bagi kehidupannya yang akan datang. Selain itu setelah diberikan intervensi menggunakan pendekatan konseling singkat berorientasi solusi dengan strategi konseling kelompok, siswa tidak hanya dapat mengurangi perilaku agresifnya tetapi siswa juga mampu menjalin persahabatan yang baik dengan temantemannya yang selama ini memiliki konflik karena sering menampilkan perilaku kekerasan terhadap teman-temannya, selain itu siswa juga dapat menyesuaikan diri dengan situasi apapun ketika berada pada lingkungannya.

Faktor yang kedua adalah dengan menggunakan boneka. Penggunaan boneka dianggap lebih efektif diberikan kepada siswa sekolah dasar karena siswa dapat sambil bermain boneka selama proses konseling sehingga konseling tidak terkesan kaku. Seperti yang diungkapkan oleh Hurlock pada dasarnya masa anak-anak sekolah dasar merupakan tahapan bermain (Hurlock, 1999). Selanjutnya dikemukakan juga oleh Bruner bahwa bermain yang dilakukan oleh anak-anak adalah suatu kegiatan yang serius dan penting untuk perkembangan tahun-tahun pertama masa anak-anak (Hurlock, 1999). Selain itu juga menurut Istati dan Rahmi bahwa anak yang menggunakan media boneka tangan akan bisa menjelajahi dan memperluas pemikirannya serta dapat memberikan dorongan kepada anak untuk mampu berinteraksi dan berpetualang (Istati \& Rahmi, 2017). Jelaslah bahwa penggunaan media boneka merupakan pilihan yang tepat untuk membantu proses konseling karena disesuaikan dengan karakteristik siswa sekolah dasar.

Faktor yang ketiga pada penelitian konseling singkat berorientasi solusi adalah peneliti memberikan reinforcement kepada siswa. Bagi siswa yang menunjukkan perilaku 
yang dapat mengendalikan perilaku agresifnya diberikan reward berupa pujian dan hadiah coklat. Reinforcement diberikan untuk memotivasi siswa agar dapat menghilangkan agresivitas yang mereka miliki, sehingga siswa dapat membentuk perilaku yang lebih baik. Hal ini sesuai dengan prosedur konseling singkat berorientasi solusi pada tahap yang terakhir yaitu siswa siminta untuk menuliskan pesan berupa pujian. Sebagaimana yang diungkapkan oleh (Walters \& Corey, 2013) bahwa untuk mengubah tingkah laku individu adalah dengan cara membetntuk perilaku yang dapat memberikan hukuman dan hadiah setelah tingkah laku yang diharapkan dapat muncul. Selain itu juga menurut (Supriyatna et al., 2014) bahwa reinforcement bertujuan untuk mengubah dan mengontrol tingkah laku tertentu sehingga perilaku tersebut berpeluang untuk terjadi atau sebaliknya berpeluang untuk tidak terjadi pada masa yang akan datang.

Faktor yang keempat adalah pada penelitian ini peneliti meminta siswa menilai diri mereka menggunakan emoticon. Skala yang digunakan pada penelitian ini merupakan emoticon, karena anak sekolah dasar memiliki kesulitan dalam menilai diri mereka menggunakan angka. Melalui emoticon ini juga anggota kelompok konseli dapat sambil bermain emoticon. Selain itu Sugara juga mengungkapkan bahwa anak-anak cenderung lebih cepat memahami melalui visual (Sugara, 2019). Faktor-faktor yang mempengaruhi keberhasilan tersebut merupakan beberapa inovasi yang dilakukan oleh peneliti karena menyesuaikan dengan karakteristik subyek penelitian yaitu siswa sekolah dasar.

Adapun karakteristik siswa sekolah dasar menurut Sumantri dan Syaodah yaitu siswa sangat senang bermain dan bergerak bebas, berminat dalam kelompok, dan senang melakukan sesuatu secara langsung (Yuyun, 2017). Jadi untuk menyesuaikan karakteristik siswa yang senang bermain dan bergerak, maka peneliti menggunakan media boneka dalam konseling sehingga siswa mengikuti konseling sambil bermain boneka. Selanjutnya peneliti juga menggunakan strategi konseling kelompok karena disesuaikan dengan karakteristik siswa yang mulai tertarik untuk berkumpul dengan kelompok, selain itu peneliti juga menggunakan emoticon sebagai pengganti pertanyaan skala karena memperhatikan perkembangan kognitif siswa yang berada pada tahap operasional konkret yaitu siswa mampu berpikir melalui benda nyata dan menyesuaikan dengan karakteristik siswa sekolah dasar yang tertarik melakukan sseuatu secara langsung.

\section{SIMPULAN}

Peneliti telah melakukan perlakuan, analisis data dan observasi kepada siswa yang memilki tingkat agresivtas tinggi. Dari hasil tersebut ditemukan kategori tingkat agresivitas siswa Sekolah Dasar di Dusun Meritai yang berada pada kategori tinggi dan sangat tinggi menurun menjadi rendah. Hal itu dapat dilihat dari deskripsi hasil pretest dan posttest agresivitas siswa. Oleh karena itu pendekatan konseling kelompok singkat berorientasi solusi dengan menggunakan media boneka dapat digunakan oleh Guru BK atau Konselor untuk membantu mengurangi tingkat agresivitas siswa.

Guru BK dapat memberikan upaya bantuan kepada siswa sekolah dasar khusunya untuk mengurangi agresivitas siswa dengan menggunakan strategi layanan konseling kelompok pendekatan konseling singkat berorientasi solusi dan menggunakan media boneka. Pendekatan ini tepat diberikan kepada siswa sekolah dasar karena sesuai dengan karakteristik siswa sekolah dasar yang senang bermain, sehingga konseling dengan menggunakan media boneka dapat memberikan kenyamanan kepada siswa selama melakukan proses konseling, selain itu siswa sekolah dasar juga memiliki minat yang tinggi untuk bergabung dan bekerja sama dalam kelompok. Sehingga strategi konseling kelompok dalam pendekatan konseling singkat berorientasi solusi yang digunakan dalam penelitian ini juga dapat dijadikan referensi bagi Guru BK untuk mengatasi masalahmasalah sosial pada siswa sekolah dasar. 


\section{UCAPAN TERIMAKASIH}

Ucapan terimakasih diucapkan kepada kemenristekdikti yang telah mendanai penelitian ini, selain itu juga kepada ketua dan staff LPPKMK Universitas PGRI Palembang yang telah membantu memfasilitasi dan memberikan informasi kepada penulis untuk mendapatkan hibah penelitian dari kemenristekbrin sampai terbitnya artikel ini. Terimakasih juga kepada orang tua dan siswa kelas III Sekolah Dasar di Dusun Meritai yang telah bersedia untuk menjadi konseli dalam konseling singkat berorientasi solusi.

\section{DAFTAR PUSTAKA}

Abdi, A. P. (2019). 24 Kasus Anak di Sekolah pada Awal 2019 Didominasi Kekerasan. Tirto.Id.

Abidin, Z. (2009). Optimalisasi Konseling Individu dan Kelompok untuk Keberhasilan Siswa. INSANIA : Jurnal Pemikiran Alternatif Kependidikan, 14(1), 132-148.

Baskoro, D. S. B. (2013). Model solution focused brief group therapy untuk perilaku agresif remaja. Jurnal Sains Dan Praktik Psikologi, 1(1).

Berkowitz, L. (1993). Aggression: Its causes, cosequences, and control. Aggressive Behavior.

BPS. (2018). Profil Anak Indonesia.

Buss, A. H., \& Perry, M. (1992). The Aggression Questionnaire. Journal of Personality and Social Psychology, 63(3), 452-459.

Estévez López, E., Pérez, S. M., Ochoa, G. M., \& Ruiz, D. M. (2008). Adolescent aggression: Effects of gender and family and school environments. Journal of Adolescence, 31(4), 433-450.

Fitri, E. N. \& M. (2016). Dalam Menyelesaikan Masalah Pribadi Siswa. Jurnal Education, 2, 19-24.

Fitriyah, F. K. (2014). Efektivitas Konseling Singkat Berfokus Solusi Untuk Mereduksi Perilaku Agresif Siswa: Penelitian Subjek Tunggal terhadap 6 Siswa SMAN 1 Singgahan Kabupaten Tuban Tahun Ajaran 2013/2014 [Universitas pendidikan Indonesia].

Goldstein, S. E., Young, A., \& Boyd, C. (2008). Relational aggression at school: Associations with school safety and social climate. Journal of Youth and Adolescence, 37(6), 641-654.

Hastuti, L. W. (2018). Kontrol Diri dan Agresi: Tinjauan Meta-Analisis. Buletin Psikologi, 26(1), 42-53.

Hurlock, E. (1999). Suatu Pendekatan Sepanjang Rentang Kehidupan. Alih bahasa: Istiwidayati \& Soedjarwo (Istiwidayati \& Soedjarwo (ed.); Edisi ke 5).

Istati, M., \& Rahmi, N. (2017). Penguatan keterampilan konseling anak: memilih media dan aktivitas yang tepat. Proceeding seminar dan lokakarya nasional revitalisasi laboratorium dan jurnal ilmiah dalam implementasi kurikulum bimbingan dan konseling berbasis kkni, 4-6.

Kegley, J. B. (2000). Perceptions of Elementary School Counselors Regarding the Utility of Solution-Focused Brief Counseling In the School Setting. In This study examined the perceptions of elementary school counselors regarding their experience in using solution-focused brief counseling for meeting the demanding responsibilities of their job and the particular needs of the students they serve. Specific (Vol. 53, Issue 9).

Kemendikbud, D. G. dan T. K. (2016). Panduan Operasional Penyelenggaraan Bimbingan dan Konseling Sekolah Menengah Kejuruan. 1, 172. 
Kronenberger, W. G., Mathews, V. P., Dunn, D. W., Wang, Y., Wood, E. A., Giauque, A. L., Larsen, J. J., Rembusch, M. E., Lowe, M. J., \& Li, T. Q. (2005). Media violence exposure and executive functioning in aggressive and control adolescents. Journal of Clinical Psychology, 61(6), 725-737.

Muh. Chotim, Dian Ratnaningtyas Affifah, dan N. K. D. (2011). Mengurangi Tingkat Agresivitas Anak Usia TK melalui Terapi Bermain (Play Therapy). 1-13.

Nasrina Nur Fahmi, S. (2016). Layanan Konseling Kelompok Dalam Meningkatkan. Jurnal Layanan Konseling Kelompok, 13(1), 69-84.

Ondawati. (2019). Upaya Menurunkan Perilaku Agresif melalui Pemberian Layanan Konseling Kelompok pada Siswa. Jurnal Penelitian Pendidikan, 19(1), 84-95.

Prayitno, Afdal, Ifdil, Z. A. (2017). Layanan Bimbingan Kelompok \& Konseling Kelompok yang Berhasil. Ghalia Indonesia.

Putri, D. A., Saputra, W. N. E., Hartanto, D., \& Nugraha, A. (2019). The Effectiveness of Solution Focused Brief Counseling (SFBC) Based on Creative Art to Reduce Students Social Aggressive Behaviour. Jurnal Nusantara of Research, 6(2), 6067.

Rangga Erfizal. (2019, November 29). Siswa SMA Taruna Indonesia Palembang Kembali Jadi Korban Kekerasan. IDN Times Sumsel.

Riski Maruto. (2020). Kakak tikam adik hingga tewas karena berkata kasar. Antara Riau.

Sari, D. K. (2016). Solution focus brief group counseling: model konseling untuk mengurangi perilaku agresif siswa. Konseling Krisis.

Sari, S. P. (2017). Teknik Psikodrama dalam Mengembangkan Kontrol Diri Siswa. Jurnal Fokus Konseling, 3(2), 123.

Setiowati, E. A., Suprihatin, T., \& Rohmatun. (2010). Gambaran Agresivitas Anak dan Remaja di Area Beresiko. JIPD (Jurnal Inovasi Pendidikan Dasar), 2(1), 23-29.

Sucipto. (2016). Konseling Kelompok dengan Media Animasi untuk Meningkatkan Penyesuaian Diri Siswa Sekolah Dasar. Jurnal Konseling Gusjigang, 2(2), 133139.

Sugara, G. S. (2019). Konseling Singkat Berorientasi Solusi. Edupotensia.

Sukardi. (2000). Pengantar Pelaksanan Program Bimbingan dan Konseling di Sekolah. Rineka Cipta.

Supriyatna, A., Konseling, B., \& Magelang, U. M. (2014). Konseling Kelompok Teknik Reinforcement Untuk Meningkatkan Kedisiplinan Siswa. Jurnal Penelitian Dan Artikel Pendidikan, 26-30.

Vega, A. De, Hapidin, H., \& Karnadi, K. (2019). Pengaruh Pola Asuh dan Kekerasan Verbal terhadap Kepercayaan Diri (Self-Confidence). Jurnal Obsesi: Jurnal Pendidikan Anak Usia Dini, 3(2), 433.

Wallace, A., \& Mishina, L. (2004). Relations Between the use of Puppetry in the Classroom, Student Attention and Student Involvemen. In Brooklyn College.

Walters, L. H., \& Corey, G. (2013). Theory and Practice of Counseling and Psychotherapy. In Family Relations (Ninth Edit).

Yuyun, D. H. (2017). Model Problem Based Learning Membangun Kemampuan Berpikir Kritis Siswa Sekolah Dasar. Journal Cakrawala Pendas, 3(9), 57-63. 